\title{
CORPORATE FOUNDATION'S RELATIONSHIP WITH THE FOUNDING COMPANY AND ITS ROLE IN IMAGE BUILDING AND CORPORATE COMMUNITY INVOLVEMENT PROGRAMMES
}

The research presented in this article analyses the mutual relations between corporate foundations and their founding companies, as well as the roles foundations play in building the company's image and CCI programmes. In order to achieve this goal, the author presents selected theoretical approaches and own research results that were part of a project entitled Corporate foundation as a tool for realizing the company's social goals, financed by the National Science Centre in Krakow.

Keywords: Corporate Community Involvement, Corporate Reputation, Public Relation, Corporate Fundation

DOI: $10.15611 /$ aoe.2015.2.09

\section{INTRODUCTION}

In recent years one could note the growing number of corporate foundations in Poland and the significant increase in their impact on the founding companies. This tendency may be attributed to the role of CCI (Corporate Community Involvement, Corporate Community Investment) among companies in Poland and around the world.

Helping to raise awareness about the firm' ${ }^{1}$ engagement in CCI is one of the main goals of a corporate foundation. Usually the foundation's website can serve as a good source of this type of information. According to their charter and the officially proclaimed goals, many corporate foundations concentrate on solving social problems and reacting to unsatisfied social needs. Their goal is to bring public benefit and serve as "antennas" or "sensors" receiving social needs and expectations.

This gives the foundations more insight into the needs and expectations of the firms' stakeholders. Thus corporate foundations can strengthen company communication on CCI and serve as a dialogue platform

\footnotetext{
* Department of Business Economics and Organization, Wrocław University of Economics

${ }^{1}$ The term "firm" in this article will be used to express the same meaning as "company".
} 
embracing stakeholders and public relations. Going one step further, corporate foundations can play an important role in shaping and strengthening a company's reputation.

The research presented in this article analyses the mutual relations between corporate foundations and their founding companies, as well as the foundation's roles in building the company's reputation and social involvement programmes.

\section{THEORETICAL BACKGROUND}

\subsection{Corporate community involvement}

In times of public opinion's growing scepticism towards corporate ethics, especially after a series of financial and industrial scandals, those companies which can demonstrate a real impact in solving social matters enjoy much more credibility than those which are mere donors even if they are donating on a large scale (...) the best way to solve many of the world's problems is by mobilizing the corporations to actions that can bring benefits both to the communities and to the companies themselves ${ }^{2}$.

These actions are called Corporate Community Involvement (CCI). Community involvement, according to the World Economic Forum definition, is the input that a company or a citizen provides through activities, charity programmes and public reform ${ }^{3}$. It also covers other forms of activities as long as they are concerned with social problem solving and bring benefits both to the company and society, regardless of the tools or programmes used ${ }^{4}$. CCI can be perceived through the prism of the force and intensity of this phenomenon and several levels of it can be distinguished. B. Rok presents four levels of community involvement.

Level 1 refers to the so called obligatory actions, which consist of the basic economic activities. At this stage the most dominating goals are

\footnotetext{
2 Porter M. E., Kramer M. R., Filantropia przedsiębiorstwa jako źródło przewagi konkurencyjnej [Philantrophy of an Enterprise as a Source of Competitive Advantage], "Harvard Business Review Polska", No 7, pp. 83-96, 2003.

${ }^{3}$ Łukasiuk P., Społeczne zaangażowanie (CCI) a społeczna odpowiedzialność biznesu (CSR). Narzędzia CCI [Corporate community involvement (CCI) vs. corporate social responsibility (CSR). CCI tools], www.corporategiving.pl.

${ }^{4}$ Odpowiedzialny biznes 2007. Raporty spoleczne i innowacyjne strategie CSR [Responsible business 2007. Social reports and CSR innovative strategies], Conference proceedings, FOB, Warszawa 2007.
} 
business goals, the company manufactures specific products or provides services. In that basic activity it uses local natural or human resources. Society benefits from access to those products, through taxes paid, other entities through cooperation with public private partnerships, and consequently it contributes to the growth of the region. Additional levels are part of the so called voluntary actions.

Level 2 consists of the commercial undertakings performed in a social context. These are planned actions designed to bring commercial success to the company and additionally also benefit the local community. These initiatives are undertaken jointly with other organizations like governmental and civic, and are one-time initiatives. Thanks to them, the regional infrastructure is evolving, there is a rise in employment and economic growth. At this stage there is also sponsorship serving the company's promotion. At the second level the business goals are still most important and the social goals are secondary, although they might be significant.

Level 3 embraces investing into the local community. They are chosen and acknowledged by the company's management as significant in supporting the company's goals and reputation and consist in solving specific social problems like increasing ecological awareness, supporting education and healthcare. They do not bring direct profits but long time benefits in the form of the desired society (healthy, educated, ecologically aware). At this level one can observe a relative balance between the business and social goals.

Level 4 is the highest level of community involvement, which is philanthropy. Apart from financial resources the company offers the competences of its employees (legal help, accounting), as well as material assistance. Philanthropy is connected to free will and selflessness, therefore business goals are secondary or irrelevant ${ }^{5}$.

Among many authors, CCI is often associated with Corporate Social Responsibility (CSR). Sometimes these terms are used interchangeably. Thus, CSR is rather a concept according to which companies willingly include social interests, environmental issues and stakeholders relations at the early stage of building corporate strategies. A socially responsible company, according to this concept, fulfils three basic goals:

- promotes responsibility as the basis of company activity,

- perfects the way the results are presented to all stakeholder groups,

\footnotetext{
${ }^{5}$ Rok B., System spolecznej odpowiedzialności [Social responsibility system], [in:] Więcej niż zysk, czyli odpowiedzialny biznes. Programy, strategie, standardy [More than Profit. The Responsible Business. Programmes, Strategies and Standards], red. Rok B., Forum Odpowiedzialnego Biznesu, Warszawa, p. 52, 2001.
} 
- supports the process of company perfection in the ethical, ecological and economic aspects.

S. Waddock points to three basic models of corporate social responsibility:

1. Social involvement model - emphasizing charity, financial and material support, staff volunteering.

2. Stakeholder model - consisting of creating relations with stakeholders.

3. Business and social efficiency model - emphasizing business growth directed to social and environmental problem solving ${ }^{6}$.

M. Porter and M. Kramer also distinguished two strategies for managing the company's CSR, focusing on the relation between the CSR activities and the main business activities of the firm ${ }^{7}$. The first strategy is the so called good citizen strategy, which consists in being involved in charity actions that have no connection with the company's activities, or in changing the overall strategy in order to decrease the intensity of its impact on the environment. The second strategy is called competitive philanthropy and consists of changing the company strategy so that it will bring more benefit to the community or involve the company more in solving social problems which can lead the company to discover new competitive advantages ${ }^{8}$.

M. Halme and J. Laurilla divide the strategies into three types: the first one is when a company gets involved in solving a problem that has no connection with the company activity, the second one involves solving the social problems that lie within the area of the company's social reach and the third one is when a company treats a social problem as an opportunity to create new products or services ${ }^{9}$.

As presented in the above examples, the connections between CCI and CSR are rather strong, since within every presented CSR model there are actions tied to community involvement that are difficult to separate. Yet it is a concept much narrower than CSR and is limited only to one stakeholder

\footnotetext{
${ }^{6}$ Waddock S., Parallel Universes: Companies, Academics, and the Progress of Corporate Citizenship, Carroll School of Management, Boston College, "Business and Society Review", Vol. 109, Issue 1, pp. 5-42, 2004.

${ }^{7}$ Porter M. E., Kramer M. R., Strategy and Society: The Link Between Competitive Advantage and Corporate Social Responsibility, "Harvard Business Review", Vol. 84, No 12, p. 85, 2006.

${ }^{8}$ Porter M. E., Kramer M. R., ibidem, p. 85.

${ }^{9}$ Halme M., Laurila J., Philanthropy, Integration or Innovation? Exploring the Financial and Societal Outcomes of Different Types of Corporate Responsibility, "Journal of Business Ethics", Vol. 84, Issue 3, p. 330, 2009.
} 
(a collective one) being the local community or society as a whole. The participants of that stakeholder also belong to other stakeholder groups (suppliers, clients, employees), therefore CCI actions also refer indirectly to those groups. Very often community involvement is identified with company philanthropy ${ }^{10}$ and is called strategic philanthropy ${ }^{11}$. "Having a CSR strategy is not obligatory to conduct strategic philanthropy, although these actions are tied to each other. Thanks to philanthropy, the company builds positive relationships with its environment, thus bringing measurable business benefits" $"$.

\subsection{Corporate community involvement in building a firm's reputation and public relations}

The reputation of a firm is defined as the networked perception of the firm's capability to fulfil the expectations of all stakeholders ${ }^{13}$. Individual ways in which stakeholders perceive the firm or how they imagine it influence this networked perception. According to Fombrun and Gardberg ${ }^{14}$, $\mathrm{CCI}$ is one of six dimensions forming individual perceptions and forming the networked perception which sums up all the individual perceptions and constitutes the firm's reputation. Therefore, while looking for ways of enhancing the company's image as a good citizen, usually the focus goes to shaping and strengthening its reputation.

Community involvement is aimed at fulfilling the social and economic needs and expectations of the local community, where the company operates. It forces the company to conduct dialogue with various stakeholder groups in order to acquire information regarding real social problems that need solving ${ }^{15}$. While conducting specific actions aimed at solving real

\footnotetext{
${ }^{10}$ Ricks J. M. Jr., Peters R. C., Motives Timing, and Targets of Corporate Philanthropy: A Tripartite Classification Scheme of Charitable Giving, "Business and Society Review", Vol. 118, Issue 3, pp. 413-436, 2013.

${ }^{11}$ Gautier A., Pache A.-C., Research on Corporate Philanthropy: A Review and Assessment, "Journal of Business Ethics", Vol. 126, Issue 3, pp. 343-369, 2015.

12 Pękacka M., Filantropia a CSR [Philanthropy vs. CSR], http://odpowiedzialnybiznes.pl/ artykuly/filantropia-a-csr/, 2011.

${ }^{13}$ Fombrun C. J., Reputation. Realizing value from the corporate image, Harvard Business School Press, Boston, MA, 1996.

${ }^{14}$ Fombrun C. J., Gardberg N., Who's tops in corporate reputation?, “Corporate Reputation Review", Vol. 3, No 1, pp. 13-17, 2000.

${ }^{15}$ Wang H., Qian C. (2011), Corporate philanthropy and corporate financial performance: The roles of stakeholder response and political access, Academy of Management Journal, 54(6).
} 
problems, companies spread information about their achievements in specific areas. The information influences the way companies are perceived. They strengthen the company's image, therefore PR activities are also used in order to achieve the desired effect.

PR's main objective should be to determine the stakeholders, examine their interests, analyse their needs and on that basis formulate the economic, legal and social obligations towards them ${ }^{16}$. According to J. Saunders, companies must show that they understand controversial issues and do something about them, and that is what good and effective PR is all about ${ }^{17}$. Apart from that, a research conducted by the Council of Foundations shows that a company's increase in community involvement by 1 unit has improved the firm's reputation by 0.27 for production companies and by 0.55 for trading companies. An increase of reputation by 1 unit, however, caused an increase of customer loyalty by 0.42 and 0.32 units respectively ${ }^{18}$.

Taking into consideration these and other research results, it is justified to use PR in communicating the company's social activities to stakeholders. We can distinguish various models of PR communication, and those most commonly used were suggested by E. Gruning and T. Hunt ${ }^{19}$ :

1. Information activity model - consisting in spreading information through one-way communication.

2. Asymmetric communication model - consisting in arguing and persuasion; communication is two-way with the bias on one side.

3. Symmetric communication model - consisting in mutual understanding of the sides and there is a noticeable balance between the partners.

If a company performs CCI activities without embedding them in a wider CSR strategy, the most common outcome is PR activities associated with the company's image. The activities being undertaken are not tied to its core business activity and social involvement programs are used by the PR department to enhance and integrate the company's image and reputation.

\footnotetext{
${ }^{16}$ Daugherty E. L., Public Relations and Social Responsibility. Handbook of Public Relations, ed. R. L. Heath, Sage Publication, Thousand Oaks, London, 2000, p. 401.

${ }^{17}$ Saunders J., Jakość, standardy i efektywność - wyzwanie czy codzienność polskiego public relations [Quality, standards and efficiency - a challenge or reality of PR in Poland?] A statement during the 2005 PR Forum, 24.11.2005.

${ }^{18}$ Measuring the Business Value of Corporate Philanthropy. Research report executive summary, October 2000, Walker Information, Inc., For the Council on Foundations.

${ }^{19}$ Kunczik M., Public relations. Konzepte und Theorien, Böhlau Verlag, Köln, p. 125, 2002.
} 
If CCI becomes part of the CSR strategy, then we would be dealing with the three available PR models of communication suggested by Gruning and Hunt and completed by Mette Morsing and Majken Schultz ${ }^{20}$.

1. PR focused on the company's image (informing PR), which appears alongside CCI in order to inform the stakeholders about positive decisions and actions. The stakeholder's role is passive.

2. PR focused on relationships (responding PR) aimed at building relationships with key stakeholders and verifying their opinions about the company; this is a two-way asymmetrical model. The stakeholders' role is partly active since they are expected to respond to the company's actions.

3. Social PR (involving PR), which uses communication to conduct systematic and pro-active dialogue with stakeholders through their involvement and direct participation. It is used to search for innovative ideas possible to use in everyday company activity.

PR, understood as corporate communication, plays a key role in building relationships with key stakeholders ${ }^{21}$. The most commonly used tool in communication with key stakeholders are reports describing either CCI or CSR. The reasons for publishing CSR reports according to managements' opinions among the world's 250 largest corporations are: ethical reasons $69 \%$, economic reasons $68 \%$, brand reputation improvement $55 \%$, innovation and learning 55\%, employee motivation 52\%, management and risk reduction $35 \%{ }^{22}$.

According to Cutlip et al., due to the rising popularity of CCI and changes in ethical norms, it becomes more and more obvious that PR specialists within the corporate environment are key figures in making policies and creating CCI programmes for their organizations ${ }^{23}$. Consequently, PR's main objective is to strategically shape CCI and communicate it to persons outside and within the company.

${ }^{20}$ Morsig M., Schultz M., Corporate Social Responsibility Communication: Stakeholder Information, Response and Involvement Strategies, "Business Ethics: A European Review", Vol. 15, No 4, 2006, pp. 323-338.

21 Olędzki J., Public Relations $w$ komunikowaniu spolecznym $i$ marketingu, Instytut Dziennikarstwa Uniwersytetu Warszawskiego, Warszawa, 2010, p. 357.

22 KPMG International Survey of Corporate Responsibility Reporting 2008, KPMG International, Amstelveen, October 2008, p. 18.

${ }^{23}$ Dozier D. M., Grunig L. A., Grunig J. E., Manager's Guide to Excellence in Public Relations and Communication Management, Lawrence Erlbaum Associates, Mahwah, NJ, 1995. 


\subsection{Corporate foundations and their role in reputation building and the PR actions of mother companies}

Corporate foundations are specific due to the fact that they are founded by a company. The goals and motivations for their establishment in Poland are influenced by the legal framework. Corporate foundations are exempt from company income tax if they act for the public benefit only.

The funds have to be spent on specific goals, determined by the founder in the foundation's charter. This means that foundations' perspectives are long term and that they are financially independent from the company's interests and financial situation. Therefore corporate foundations have some freedom in experimenting and discovering new or less popular fields. They can be innovative, future oriented, entrepreneurial and active without running much risk ${ }^{24}$. Indeed, corporate foundations are often described as initiators of change and have even been called "indispensable elements of anarchy" 25 .

Numerous researches show that the basic motivation for establishing a foundation declared by companies is first of all the possibility to create a separate management structure for their charitable actions without overburdening regular company staff. Secondly, it allows for the creation of an integrated and long-term CCI strategy. The third reason is the owners' or founders' personal motivation, and the fourth - the reputation benefits for the founding body ${ }^{26}$.

Based on empirical research conducted among 300 students, J. Marquardt ${ }^{27}$ states that corporate foundations are the right PR instrument and can have a positive influence on the company's credibility and image. One can also assume that corporate foundations can be perceived as more neutral and objective than the companies themselves, therefore they can be more credible in terms of CCI activities.

In order to support the creation of PR and the company reputation, the work of the two organizational entities has to be coordinated, and structures

\footnotetext{
${ }^{24}$ Westhues M., Einwiller S., Corporate Foundations: Their Role for Corporate Social Responsibility, "Corporate Reputation Review", Vol. 9, No 2, 2008, pp. 144-153,

${ }^{25}$ Strachwitz (Graf) R., Stiftungen - nutzen, führen und errichten: ein Handbuch, Campus, Frankfurt, 1994.

26 FOB o fundacjach korporacyjnych [FOB about corporate foundations], www.odpowiedzialnybiznes.pl.

27 Marquardt J., Corporate Foundation als PR-Instrument. Rahmenbedingungen Erfolgswirkungen - Management, Gabler, Wiesbaden, 2001.
} 
for the transfer of experience and information have to be implemented. For a better understanding of the possible practices and cooperation, empirical research was conducted.

\section{RESEARCH CHARACTERISTICS}

The research presented in this paper is part of a project entitled Corporate foundation as a tool for realising the company's social goals, financed by the National Science Centre in Krakow. The following research problem was defined: Whether and in what circumstances the corporate foundation is a proper tool to perform the CCI? The main research goal is the analysis and evaluation of the practice of creating and functioning of corporate foundations in Poland. The cognitive research goals are:

1. Determination of the reasons and motives for creating corporate foundations, and of the roles they play for their mother companies.

2. Analysis and evaluation of corporate foundations' operations including goals and forms of activity, the addressees, institutional structure, financing sources, ways of spending, and measuring the effects.

3. Evaluation of the consequences of the corporate foundations operations to the mother companies and their environment.

Bearing in mind the detailed and multidimensional examination of corporate foundation's activities, the author decided to take the positivistic paradigm and nomothetic approach as well as the grounded theory methodology. The methodological procedure was triangulation, which is typical in the quantitative and qualitative approach.

The following methodology was used to analyse the corporate foundations and their founding companies: quantitative research (questionnaire) and qualitative research (individual in-depth interview) conducted among chosen corporate foundations and companies using case study, observation and documentation analysis (including websites of companies and their foundations).

The research sample was carefully chosen. The research was based on 50 interviews conducted in 72 identified and actively operating corporate foundations in Poland and in 27 founding companies. The respondents were the CEOs and foundation board members. 


\section{RESEARCH RESULTS}

\subsection{Structural, formal and informal ties between the foundation and the founding company}

The strongest structural tie between the foundation and the founding company is the foundation's board and management. In 33 cases the foundation's board (in 23 cases this is a 100\% share) and management (in 20 cases a $100 \%$ share) is made up of higher and top management representatives of the founding company such as a former or present CEO, top managers and board members. These persons are considered to be a significant communication channel between the two entities, since information about the foundation's activities regularly flows from the foundation's board to the company's management through its representatives on the board.

Furthermore, foundations communicate with specialists from CSR, PR and marketing divisions and through company staff engaged in the foundation's activities, which is a common phenomenon. Another element that supports this process is the mutual adjustment of the company's and the foundation's visual identification systems. In two companies, the exchange of information and experience was organized by a knowledge exchange platform localized in the founding company or by special work teams.

The information flow between the company and the foundation is usually informal, direct and verbal. This happens through emails, telephone calls, meetings and reports on the foundation's operations. In all the researched cases, information about the foundation's activities was submitted to company employees on paper or through the Internet. Corporate brochures and magazines regularly publish ("short, easy to absorb") articles about the foundation's activities. Financial and operational reports are also placed on the company's intranet.

It was explained by companies' representatives that this type of information is passed on due to the feeling of obligation towards stakeholders, in order to show them "where the money went" and also in order to attract new funding and increase employee involvement in social activities. Sometimes information about the foundation's activities is passed to the media and to the company's clients in order to build a positive image and a network of contacts and also for the better identification of the social needs within the foundation's operating area. 


\subsection{Foundation's role in the company and possible conflicts}

The majority of respondents from the founding companies perceive the foundation's role as an expression of the founding company's CCI strategy or its application. It was highlighted that by definition, the foundation expresses long-term institutionalized CCI and implements it. Additionally, foundations achieve the company's social communication, marketing and PR goals and systemize the company's social activities. The reasons officially declared as founding goals are: a conviction of the need to bring help, building social trust towards the company, responding to social expectations and building company image or brand.

Persons participating in the interview acknowledged the existence of the image benefits for companies stemming from owning a foundation. It was stated that the effect of image transfer will appear as long as the company's name will be a part of the foundation's name, no matter how independent the foundation may be. The coinciding of the company's and the foundation's name was confirmed by 33 of the 50 surveyed foundations, and 25 of those 33 perceive that coincidence as beneficial to the company. Foundations also acknowledge their own benefits like: more social trust, prestige, recognition, operational professionalism and increased employee involvement (as volunteers) in the foundation's work.

The benefits for the founding company are perceived by the surveyed companies as long-term and indirect, society was considered to be the main beneficiary. The foundation was described as a source of information to the company about social needs and also as a tool for building long-term relationships between the company and society. It allows for acquiring and accumulating experience in socially responsible matters and enhances the company's networking. The companies' representatives also noted that the foundation can be a "pioneer" in new markets, gain know-how and provide recognition for the company.

In terms of threats and difficulties stemming from the foundation's tie to the company, the responding company representatives pointed to the financial dependence and the necessity for the company to provide stable long-term financing. In case of a market crisis this can create a series of problems since the company is responsible for the foundations, its partners and beneficiaries. The majority of respondents from the companies identified a conflict between the foundation's independence and the founding company's interests. These observations are confirmed by the respondents representing the foundations who noted that there are difficulties in establishing the foundations' goals and their hierarchy. Company 
representatives within the foundation's structures are prone to goals that guarantee image benefits to the company. In the opinion of companies' respondents, if the foundation is not transparent and its goals are not integrated with the corporate social goals it can either negatively influence the company's image or not influence it at all.

A few respondents clearly stated that this conflict is inevitable because the company's interests are difficult to align with the foundation's interests and their objectives are different. Other respondents highlighted the fact that the company does not interfere with the foundation's interest or does not take full advantage of the foundation's potential. The necessity to educate company staff about the foundation's significance to their company's operation is also considered a problem.

\subsection{Dialogue with stakeholders, identifying problems}

What results from the surveys conducted among the foundations is that the vast majority of foundations identify their stakeholder groups, the most important of which are the beneficiaries of foundations' actions, public institutions, other non-profit organizations, the media and companies. In the case of the surveyed companies, the most important groups are clients, employees, the local community, local authorities, contractors and the media. Additionally, the representatives of the surveyed companies pointed out that some stakeholder groups are more important to the company than to the foundation, such as: suppliers, clients, contractors, the media, employees, local authorities and the company's top management.

In the case of stakeholder groups such as: the beneficiaries of the foundations' actions, other non-profit organizations and the local community; the respondents from among the companies stated that they are more important to the foundation than to the company. Foundations also try to identify opinion leaders within particular stakeholder groups and communicate with them through direct meetings, telephone calls, emails, events and transmitting information about the foundation. Dialogue with stakeholders is used by the foundations to plan actions, verify them and improve promotional activities.

Many of the researched companies receive information about the foundation's dialogue with stakeholders. The information is then used by companies in their CCI strategy and program building; in establishing relationships with clients, stakeholders and opinion leaders; in image building, and finally in preparing reports on the company's CCI activities. It 
is also used by the company for the better recognition of the foundation's needs and their fulfilment. Information flowing from the foundation also allows the company to better recognize the needs of its operational environment and adjust its programmes accordingly.

An important body acting towards the integration of the stakeholders' perspectives into the foundation's strategy is the foundation's board or programme committee. Its principal task is counselling for the foundation on the goals of its actions both at strategic level and at the level of specific programs. Foundation stakeholders are directly represented in this decisive body only in 10 out of the 50 surveyed foundations.

Companies also inform the media and clients about the actions performed by the foundations specifically for the purpose of the company's image and PR. To this end they use mostly the mutual adjustment of visual identification systems and the company-foundation name coincidence, Internet and employee personal contacts.

All respondents from the foundations mentioned the media as one of the most important stakeholder groups. Ties to the media were perceived as significant tools for spreading information about initiatives and the foundation's results and media messages about the foundation's operations are intended and welcome. Media relationships were somehow perceived as a difficult task for the foundation. It was commented on that it is difficult to achieve good communication in the media because a good news is no news. In cases where the media did publicize the foundation's actions, information about the ideas and sponsors behind them was rarely included. Media messages on the ideas and concepts related to the foundation's initiatives were considered important because "stakeholders often don't understand that foundations do follow a strategy and not just randomly give money away".

The foundations create an objective and financial report (49 out of 50 surveyed) on their activities in the form of a write-up and publish it on their website, make it available at their headquarters or deliver it to the relevant institutions such as the Ministry of Health, the Ministry of Labour, Tax Office, etc. The yearly report is considered rather a legal obligation but also a tool for promoting and communicating the foundations' activities.

Information regarding their corporate foundations were published by 42 out of 75 companies that have a website. While 32 companies have a common website with their foundations, 67 foundations have their individual websites which are usually passive and communicate only one way. Stakeholders and third parties do not co-create the websites nor have the opportunity to post comments. 


\section{RESEARCH INTERPRETATION AND IMPLICATIONS}

Having analyzed the role that corporate foundations play for their founding companies, the reasons for their creations and the goals they achieve, it could be concluded that corporate foundations in Poland seem to be an expression of CCI and/or CSR strategy. The analysis of the surveyed foundations' and their founding companies' communication processes allows us to state that there are two dominating PR communication models from the Gruning and Hunt classification: the informing PR and the asymmetrical communication model. Additionally it seems that PR activities support the communication processes and relationship building with stakeholders in order to enact CCI both for the founding company as well as for the corporate foundations.

A deeper analysis of the research results shows that the activities of the surveyed foundations and their founding companies prefer a relationshipand image-focused PR, while social PR is not yet popular. There are attempts to use communication to conduct a systematic and proactive dialogue with stakeholders through their involvement and direct participation, e.g. in decision making, but these attempts are very scarce among the Polish foundations. Despite the fact that the respondents did not notice (or did not admit to) tensions in the relationship between the company and the foundation, it did not turn out to be an easy one.

The foundation's board plays a key role in many ways: as a decisive body for the strategy behind the foundation's activities and as a key communication channel with the company. The intensive placement of the company's top managers on that board represents how significant the foundation is to the company. It also increases the foundation's significance to internal and external stakeholders as long as the board is acknowledged and identified by them. Accepting stakeholder representatives into the foundation's decisive body seems to be the first step towards a better understanding of their needs. In this environment it also helps to increase the transparency of the decision making processes.

A systematic approach to creating, updating and distributing knowledge turns out to be very important for the proper distribution of information prepared by the foundation. This can significantly increase the foundation's impact. Internet media and knowledge management systems can also fulfil this task and the majority of foundations already share information about their actions and results on the Internet. In order to improve knowledge transfer during personal contact, it is advised that a representative of the 
founding company responsible for CCI strategy is a member of the foundation's board. In order to verify whether information distributed on paper and via Internet really does reach its designed recipients and achieve the desired effect, separate research should be conducted.

One of the ways to broaden the foundation's social recognition and knowledge about its activities is to increase the number of media messages regarding the foundation. In order to achieve this, perhaps placing local media representatives on the foundation's board might help. Finally, it should be emphasized that the presented research results regard only Polish foundations. Since managing a corporate foundation is subject to legal and cultural frameworks, it would be interesting to compare the approach to corporate foundations and their managements' role in CCI improvement and company-stakeholder dialogue with other countries and legal frameworks.

\section{REFERENCES}

Cutlip, S. M., Center, A. H., Broom, G. M., Effective Public Relations, 8th ed., Prentice-Hall, Upper Saddle River, NJ, 1999.

Daugherty, E. L., Public Relations and Social Responsibility. Handbook of Public Relations (ed.) Heath, L. R.. Sage Publication, Thousand Oaks, London, 2000.

Dozier, D. M., Grunig, L. A., Grunig, J. E., Manager's Guide to Excellence in Public Relations and Communication Management. Lawrence Erlbaum Associates, Mahwah, NJ, 1995.

FOB o fundacjach korporacyjnych [FOB About Corporate Foundations], www.odpowiedzialnybiznes.pl.

Fombrun, C. J., Gardberg, N., Who's Tops in Corporate Reputation?, “Corporate Reputation Review", Vol. 3, No 1, pp. 13-17, 2000.

Fombrun, C. J., Reputation. Realizing Value from the Corporate Image. Harvard Business School Press, Boston, MA 1996.

Gautier, A., Pache, A.-C., Research on Corporate Philanthropy: A Review and Assessment, "Journal of Business Ethics", Vol. 126, Issue 3, pp. 343-369, 2015.

Halme, M., Laurila, J., Philanthropy, Integration or Innovation? Exploring the Financial and Societal Outcomes of Different Types of Corporate Responsibility, "Journal of Business Ethics”, Vol. 84, Issue 3, pp. 325-339, 2009.

Kunczik M., Public relations. Konzepte und Theorien, Böhlau Verlag, Köln, 2002.

Łukasiak, P., Społeczne zaangażowanie (CCI) a społeczna odpowiedzialność biznesu (CSR). Narzędzia CCI [Corporate Community Involvement (CCI) vs. Corporate Social Responsibility (CSR). CCI Tools], www.corporategiving.pl, 2008.

Marquardt, J., Corporate Foundation als PR-Instrument. Rahmenbedingungen Erfolgswirkungen - Management, Gabler, Wiesbaden, 2001.

Morsig M., Schultz M., Corporate Social Responsibility Communication: Stakeholder Information, Response and Involvement Strategies, "Business Ethics: A European Review", Vol. 15, No 4, pp. 323-338, 2006. 
Odpowiedzialny biznes 2007. Raporty spoleczne i innowacyjne strategie CSR [Responsible Business 2007. Social Reports and CSR Innovative Strategies], Conference proceedings, FOB, Warszawa 2007.

Olędzki J., Public Relations w komunikowaniu społecznym i marketingu [Public Relations in Social Communication and Marketing], Instytut Dziennikarstwa Uniwersytetu Warszawskiego, Warszawa, 2010.

Pękacka, M., Filantropia a CSR [Philanthropy vs. CSR], http://odpowiedzialnybiznes.p1/ artykuly/filantropia-a-csr/, 2011.

Porter, M. E., Kramer, M. R., Strategy and Society: The Link Between Competitive Advantage and Corporate Social Responsibility, "Harvard Business Review", Vol. 84, No 12, pp. 78-92, 2006.

Porter, M. E., Kramer, M. R., Filantropia przedsiębiorstwa jako źródto przewagi konkurencyjnej [Philantrophy of an Enterprise as a Source of Competitive Advantage], "Harvard Business Review Polska", Nr 7, pp. 83-96, 2003.

Ricks, J. M. Jr., Peters, R. C., Motives Timing, and Targets of Corporate Philanthropy: A Tripartite Classification Scheme of Charitable Giving, "Business and Society Review" Vol. 118, Issue 3, pp. 413-436, 2013.

Rok, B., System spotecznej odpowiedzialności [System of Social Responsibility] [in:] Rok, B. (ed.) Więcej niż zysk, czyli odpowiedzialny biznes. Programy, strategie, standardy [More than Profit. The Responsible Business. Programmes, Strategies and Standards]. Forum Odpowiedzialnego Biznesu, Warszawa, 2001.

Saunders, J., Jakość, standardy i efektywność - wyzwanie czy codzienność polskiego public relations? [Quality, Standards and Efficiency - A Challenge or Reality of PR in Poland? A statement during the 2005 PR Forum, 24.11.2005.

Strachwitz (Graf) R., Stiftungen - nutzen, führen und errichten: Ein Handbuch, Campus, Frankfurt 1994.

Waddock, S., Parallel Universes: Companies, Academics, and the Progress of Corporate Citizenship, Carroll School of Management, Boston College, "Business and Society Review", Vol. 109, Issue 1, p. 5-42, 2004.

Wang, H., Qian C., Corporate Philanthropy and Corporate Financial Performance: The Roles of Stakeholder Response and Political Access, "Academy of Management Journal”, Vol. 54, No 6, pp. 1159-1181, 2011.

Westhues, M., Einwiller, S., Corporate Foundations: Their Role for Corporate Social Responsibility, “Corporate Reputation Review”, Vol. 9, No 2, pp. 144-153, 2008.

Received: March 2013, revised: October 2015 